\title{
Diversity of Macrophytes and Environmental Assessment of the Ljubljanica River (Slovenia)
}

\author{
Mateja Germ, Vanja Janež, Alenka Gaberščik and Igor Zelnik *D \\ Department of Biology, Biotechnical Faculty, University of Ljubljana, Jamnikarjeva 101, 1000 Ljubljana, Slovenia; \\ mateja.germ@bf.uni-lj.si (M.G.); vanja121@gmail.com (V.J.); alenka.gaberscik@bf.uni-lj.si (A.G.) \\ * Correspondence: igor.zelnik@bf.uni-lj.si; Tel.: +386-1-3203339
}

\begin{abstract}
The present research aimed to determine the diversity of macrophyte taxa in the Ljubljanica River and its relationship with environmental parameters. In each of the 19 river sections, the presence and abundance of plant taxa were recorded, and basic physical and chemical parameters were measured. Additionally, selected environmental parameters were assessed using a modified version of the Riparian, Channel and Environmental (RCE) method. We compared the obtained data set with survey data from the year 2004. In 2019, a total of 34 macrophyte taxa were recorded. The dominant taxa with the highest abundance were Sparganium emersum, Callitriche sp., and the invasive alien species Elodea canadensis. The species richness and diversity of macrophytes decreased with distance from the source, an increase in $\mathrm{pH}$, and alterations of the riverbed structure due to interference in the riverine ecosystem in the lower part of the Ljubljanica River and its catchment. The comparison of 2004 and 2019 surveys revealed a decrease in the overall presence and abundance of $P$. natans and in the frequency of occurrence of the species Myriophyllum spicatum and an increase in the presence and abundance of the invasive alien species Elodea canadensis.
\end{abstract}

Citation: Germ, M.; Janež, V.;

Gaberščik, A.; Zelnik, I. Diversity of Macrophytes and Environmental Assessment of the Ljubljanica River (Slovenia). Diversity 2021, 13, 278. https://doi.org/10.3390/d13060278

Academic Editors: Adriano Stinca and Michael Wink

Received: 30 April 2021

Accepted: 17 June 2021

Published: 21 June 2021

Publisher's Note: MDPI stays neutral with regard to jurisdictional claims in published maps and institutional affiliations.

Copyright: (c) 2021 by the authors. Licensee MDPI, Basel, Switzerland. This article is an open access article distributed under the terms and conditions of the Creative Commons Attribution (CC BY) license (https:// creativecommons.org/licenses/by/ $4.0 /)$.
Keywords: diversity; plant species; river; environmental parameters

\section{Introduction}

Slovenia is one of the richest European countries in terms of water resources as well as biodiversity. Running waters form a dense network, except in the karst areas, where the watercourses flow underground. Anthropogenic activities generate an array of pressures that impact aquatic and riparian areas [1]. Nutrient enrichment, alteration of riparian vegetation, riverbed regulation, and alteration of the hydrological regime of the river, strongly influence the structure and function of ecosystems. Such changes significantly impact all processes within the ecosystem [2-4] as they disrupt its natural balance and ecosystem function $[5,6]$.

Macrophyte communities are fundamental for the functioning of many river ecosystems [7]. However, they respond to disturbances in ecosystems and are particularly sensitive to anthropogenic influences, which negatively impact their diversity and species composition [8,9]. Macrophyte associations depend on various abiotic and biotic factors $[10,11]$. Based on this, we can identify species that are reliable indicators of changes in river ecosystems and use them as a tool to assess the ecological status of rivers [12-14]. The presence and diversity of macrophytes depend on water quality, water depth, flow velocity, flow rate, hydrological conditions, water level, $\mathrm{pH}$, shading, and substrate characteristics [15-17]. In addition, they are also affected by biotic factors, namely the properties of species, interspecific competition, grazing, and allelopathy. Shading by riparian vegetation is an important factor in lotic ecosystems, and it also affects the distribution and abundance of aquatic plants [18]; thus, macrophyte diversity and their abundance reflect the quality of an ecosystem as a whole [19].

In recent decades, aquatic vegetation has undergone significant changes. Anthropogenic changes associated with climate change have contributed to the general decline of 
macrophyte species diversity and led to the homogenization of vegetation in many rivers worldwide [20-22]. Such changes in macrophyte communities may also have implications for other organisms due to their crucial role within river ecosystems [7]. The effects of anthropogenic activities on macrophyte diversity depend on the type of activity, its frequency and intensity, and the resistance of the ecosystem to a single load [23-25]. Intensive agricultural activity is associated with physical modifications of aquatic habitats, such as channelization of stream reaches, which alters environmental conditions that are important for the biotic communities. The mentioned influences also accelerate the spreading of IAS to which aquatic and riparian habitats are extremely vulnerable [26,27]. Macrophytes are among the biological elements identified by the Water Framework Directive (WFD) [28] for assessing the ecological status of waters. The WFD requires that the definition of the ecological status of natural water bodies is based on the comparison of chemical, hydromorphological, and biological features in surveyed and reference water bodies [29]. RCE is one of the ecomorphological analyses that evaluates the naturalness or degradation of the structure of the riverine ecosystem and provides reliable results. Methodologies used within the WFD analyze benthic invertebrates and fish for the evaluation of morphological conditions, which requires a considerable amount of money and time.

The purpose of this research was to determine the diversity, abundance, and distribution of macrophytes in the Ljubljanica River and to determine the condition of the river system based on an environmental assessment of the watercourse following the RCE method. In addition, we compared the obtained data set with survey data from the year 2004. We also sought to establish the relationships between the environmental parameters and the diversity of macrophyte taxa and the relations between physical and chemical parameters and the distribution of macrophyte taxa.

\section{Materials and Methods}

\subsection{Study Area}

The Ljubljanica River sensu stricto, which is the subject of our research, is a $41-\mathrm{km}$ long surface flow belonging to the Ljubljanica River sensu lato, which is known as the river of seven names [30]. The flow of the Ljubljanica River (s.l.), which has distinctly karst characteristics, alternates between surface sections on karst poljes and subsurface sections flowing through the cave systems in the limestone bedrock. The final section of the Ljubljanica River (s.s.) originates from karst springs near Vrhnika. It passes Ljubljana Moor and the city of Ljubljana, and, near the settlement Podgrad, it joins the Sava River. On its way, numerous tributaries of the northern and southern edges of the Ljubljana Moor flow into the river. The Ljubljanica River flows between grasslands, arable land, settlements, and through the city of Ljubljana, so it is subject to numerous anthropogenic influences. The shape of the riverbed is mostly flat, resulting from numerous regulatory interventions [31]. The river belongs to the Dinaric hydro-ecoregion; it is characterized by a medium-sized catchment.

The sampling of the first 17 sections (Figure 1) was performed from a boat. The river sections near the city of Ljubljana were sampled from the bank. When sampling macrophytes at greater depths, we used a telescopic stick with hooks, with which we were able to sample plants from the bottom of the river. Selected chemical and physical parameters in the water were measured with a multimeter (Eutech PCD-650, Singapore). 


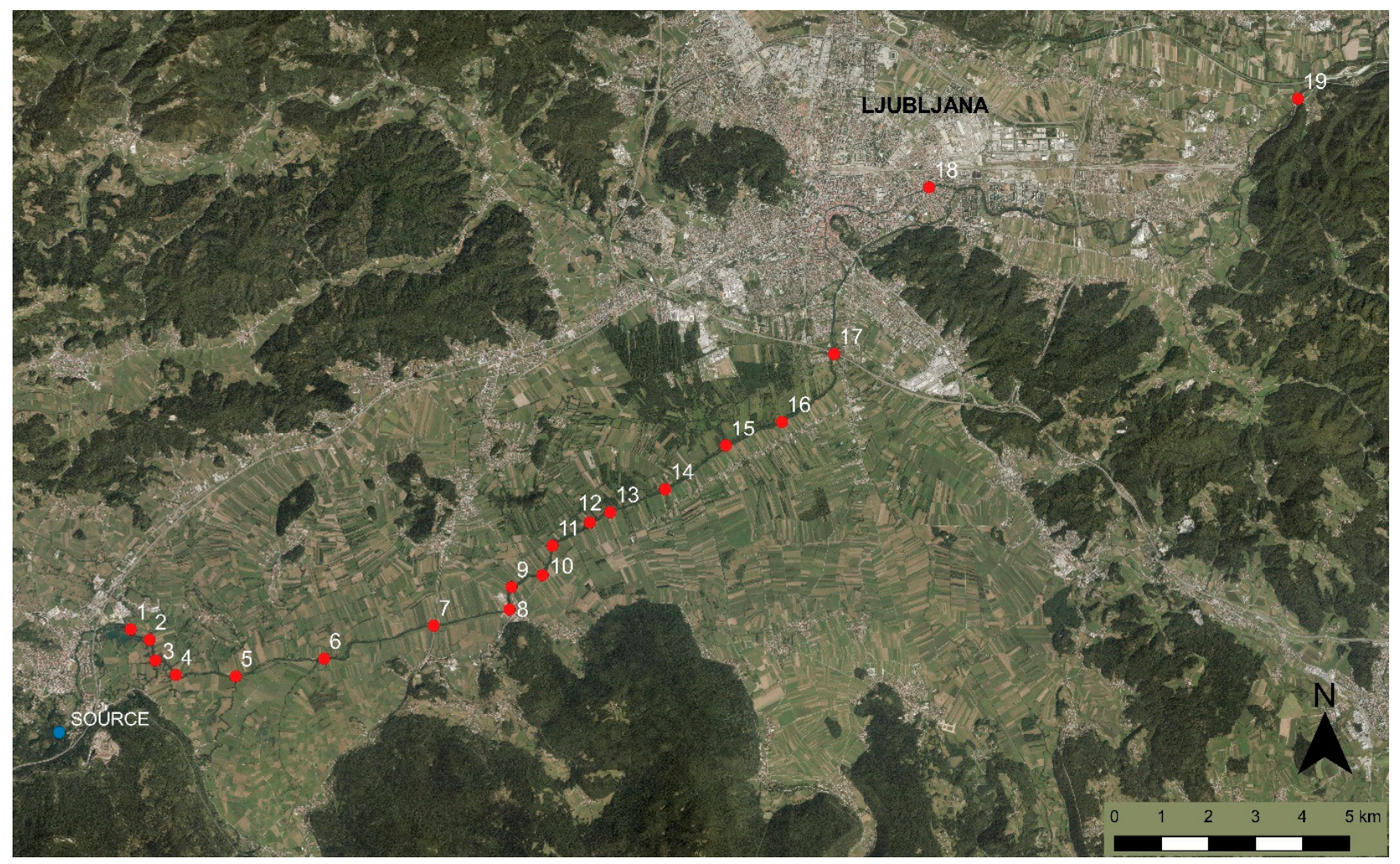

Figure 1. The spring of Ljubljanica River is marked with the blue circle on the map. The red squares and numbers from 1 to 19 indicate surveyed sections from its source near Vrhnika to the outflow river Sava (ARSO Geoportal: Atlas of the Environment).

\subsection{Macrophyte Survey and Assessment of Environmental Parameters}

The starting and end points of the sections were documented using a GPS (Global Positioning System) device. A new section started when the diversity of macrophytes, or environmental parameters-such as land-use type, riparian vegetation, or type of substratum-changed significantly. In each section, we selected a $100 \mathrm{~m}$ stretch and performed a survey of macrophytes, assessed their diversity and abundance, assessed the environmental parameters of the river ecosystem according to the RCE inventory, and measured the physical and chemical parameters of the water. The abundance of macrophytes was determined using a five-degree scale [32]. These values were transformed by the function $\mathrm{x}^{3}$, as suggested by Schneider and Melzer [33].

The RCE method is used to provide an assessment of the environmental characteristics of the watercourse, covering the physical properties of the riverbed, the properties of the riparian vegetation, and the properties of the catchment area. The modified RCE method covers a total of twelve different environmental parameters. We estimated the following RCE characteristics according to Petersen [34], where detailed descriptions are found: RCE1-Land-use pattern beyond the riparian zone (RZ); RCE2—Width of RZ; RCE3 - Completeness of RZ; RCE4-Vegetation structure of RZ within a $10 \mathrm{~m}$ channel; RCE5-Retention devices; RCE6-Channel structure; RCE7-Channel sediment type; RCE8-Bank structure; RCE9-Bank undercutting; RCE10—Stony substrate appearance; RCE11-Stream bottom interstices; RCE12-The presence of riffles and pools, or meanders. For all the characteristics, the highest values represent the most preserved or near-natural environment, while the lowest values characterize the most human-altered or most degraded environment. 


\subsection{Data Analyses}

The relative plant abundance (RPA) was used to calculate the quantitative significance of individual taxa in each river section. RPA was calculated according to the method described by Pall and Janauer [35].

Diversity was measured as the number of species and the Shannon-Wiener diversity index $\left(\mathrm{H}^{\prime}\right)$, which was calculated based on mean cover values according to BraunBlanquet [36] with PAST (version 2.17c) [37]. Correlations between explanatory variables and the diversity of the macrophytes were tested with a Kendall tau rank correlation coefficient [37].

The influence of environmental factors on the macrophyte diversity was tested by canonical correspondence analysis in the program package Canoco 4.5 [38]. The unimodal gradients in the matrix of species data were revealed beforehand with detrended correspondence analysis. The eigenvalue for the first axis was 0.69 , and the gradient length was 3.69 standard deviations [39], so canonical correspondence analyses (CCAs) were performed. Species data were $\log (x+1)$-transformed. We used forward selection, where 499 permutations were performed in every round to rank the relative importance of explanatory variables. The second and third rounds of the analysis only involved factors for which $p<0.05$ in the previous step. In addition, detrended correspondence analysis (DCA) was performed to compare the similarity of macrophyte species presence and abundance along the Ljubljanica River in 2004 [40] and 2019.

\section{Results and Discussion}

A total of 34 different macrophyte taxa were recorded in the field. Their diversity varied within individual river sections. Table 1 shows the presence of macrophyte taxa in the years 2004, when the first study on diversity of macrophytes in the Ljubljanica River was performed, and 2019.

Table 1. List of recorded macrophyte taxa in the Ljubljanica River in years 2004 (according to [40]) and in 2019. Taxa not common to both years are marked in bold.

\begin{tabular}{ccc}
\hline & Species Recorded in 2019 & Species Recorded in 2004 [40] \\
\hline 1 & Alisma plantago-aquatica & Alisma plantago-aquatica \\
2 & Alisma sp. & \\
3 & Berula erecta & Berula erecta \\
4 & Callitriche sp. & Callitriche sp. \\
5 & Carex sp. & Carex sp. \\
& & Ceratophyllum demersum \\
6 & Elodea canadensis & Chara sp. \\
7 & Equisetum palustre & Elodea canadensis \\
8 & Fontinalis antipyretica & \\
9 & Hippuris vulgaris & Fontinalis antipyretica \\
10 & Hris pseudacorus & Hippuris vulgaris \\
11 & Juncus effusus & Hottonia palustris \\
& & Iris pseudacorus \\
12 & Lycopus europaeus & Lemna minor \\
13 & Lythrum salicaria & Lemna trisulca \\
14 & Mentha aquatica & Lysimachia vulgaris \\
15 & Mentha longifolia & Lythrum salicaria \\
16 & Myriophyllum spicatum & Mentha aquatica \\
& & \\
& & Myriophyllum spicatum \\
& & Myriophyllum verticillatum \\
\hline
\end{tabular}


Table 1. Cont.

\begin{tabular}{lcc}
\hline & Species Recorded in 2019 & Species Recorded in 2004 [40] \\
\hline 17 & Myosotis scorpioides & Myosotis scorpioides \\
18 & Nasturtium officinale & Nasturtium officinale \\
19 & Nuphar luteum & Nuphar luteum \\
20 & Phalaris arundinacea & Phalaris arundinacea \\
21 & Phragmites australis & Phragmites australis \\
22 & Polygonum amphibium & \\
23 & Potamogeton crispus & \\
24 & Potamogeton lucens & Potamogeton crispus \\
25 & Potamogeton natans & Potamogeton lucens \\
26 & Potamogeton pectinatus & Potamogeton natans \\
27 & Potamogeton perfoliatus & Potamogeton pectinatus \\
28 & Ranunculus circinatus & Potamogeton perfoliatus \\
29 & Ranunculus trichophyllus & Ranunculus circinatus \\
30 & Ranunculus trichophyllus \\
31 & Sarippa sylvestris & Potamogeton filiformis \\
32 & Senecio paludosus & Rorippa amphibia \\
33 & Sparganium emersum & Sagittaria sagittifolia \\
& \\
34 & Veronica anagallis-aquatica & Sparganium emersum \\
& 34 & Typha angustifolia \\
\end{tabular}

In 2019, a total of 34 macrophyte taxa were recorded within the entire set of 19 sections of the Ljubljanica River (Figure 2). The greatest diversity of macrophyte taxa was recorded in the upper part of the river (sections nr. 1-7). We identified a significant correlation between the number of taxa and distance from the source (Table 2). The closer we got to the part of the river in the city of Ljubljana, the less diversity we found (Figure 2). The lower diversity was probably also a consequence of less natural land use, which was documented in this research (Table 2). The distribution and abundance of macrophytes along the Ljubljanica also changed (Table 1). In the upper sections, the abundance of macrophytes was high (sections nr. 1-6), but in the middle part, the species appeared with a high abundance only in certain areas, indicating worse environmental conditions and nutrient inputs from the catchment (sections nr. 11-13). Filamentous algae appeared in all examined sections, appearing with higher abundance in the lower part of the river, from sections downstream of nr. 7, and where their mats covered the macrophyte stands.

Lacoul and Freedman [41] report that $\mathrm{pH}$ and associated factors are crucial determinants of macrophyte diversity, as also shown by Ljevanaić-Mašič et al. [42]. Similar to our study, Svitok et al. [43] report that river sites with a $\mathrm{pH}$ higher than 8.4 supported significantly less macrophyte species richness than the sites with a lower $\mathrm{pH}$ did. Rosso and Fernández Cirelli [44] also reported that the higher $\mathrm{pH}$ (i.e., values above 8 ) in the prairie streams was unfavorable for macrophytes. Svitok et al. [43] claimed that the effect of $\mathrm{pH}$ is related to the physiological traits of macrophytes, as some of the aquatic macrophytes are capable of using only carbon dioxide as a carbon source, which is scarce in waters with a $\mathrm{pH}$ of 8.3 [43]. Above these values, bicarbonate ions are predominantly present [44]. 


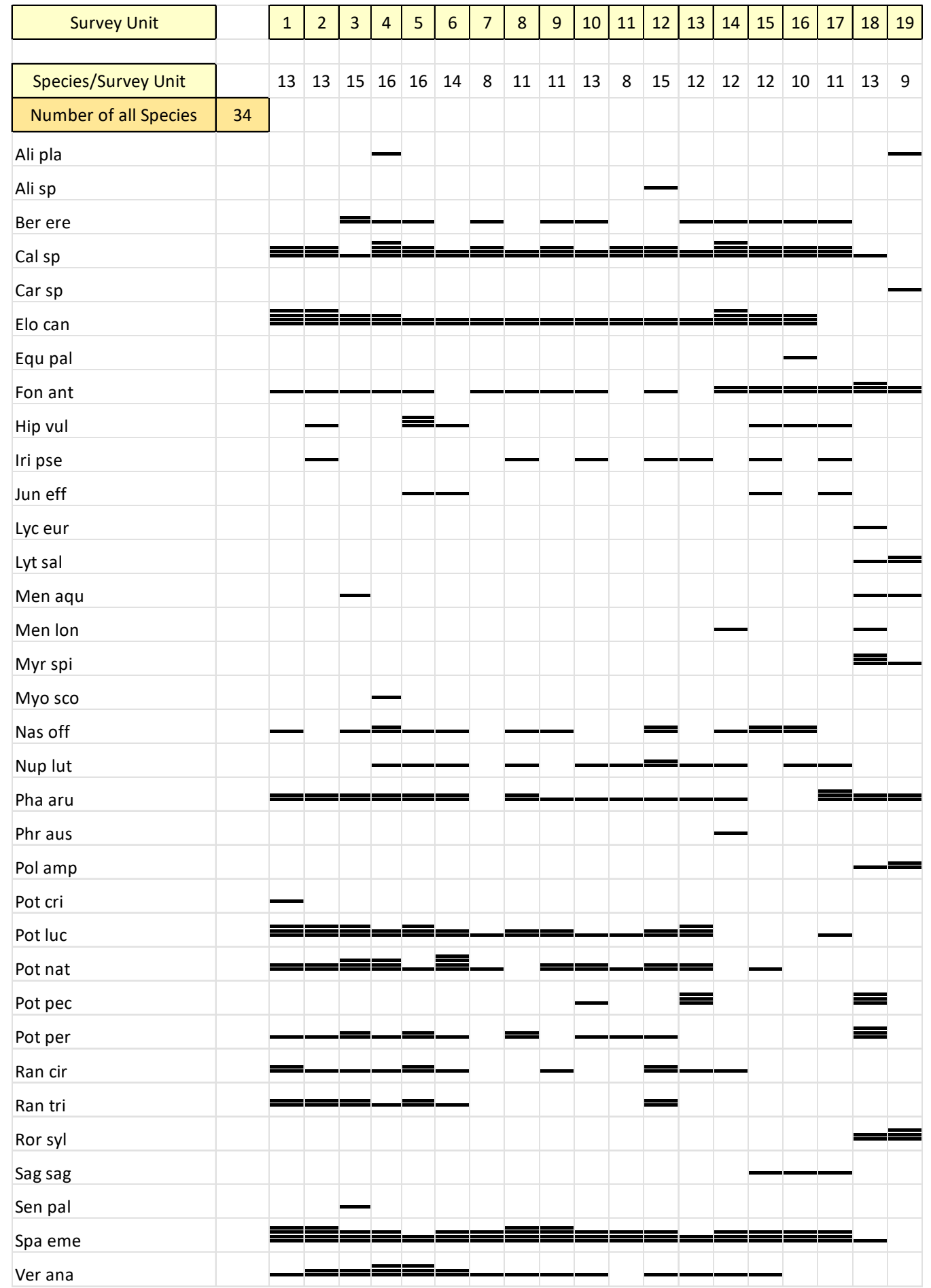

Figure 2. Diversity and abundance of macrophytes in the examined sections of the Ljubljanica River at the peak of the growing season in August 2019. The height of the black column represents the abundance of taxa from 1-5.

Unlike in this study, Svitok et al. [43] found that macrophyte diversity showed only a weak or no relationship with spatial variables on various scales. In addition, abundance of submerged and emergent macrophytes was not dependent on adjacent land use or on regional phytogeography in the prairie lotic ecosystems [44]. Alahuhta et al. [45] discovered that species richness of emergent macrophytes in lakes was best explained by the land use in 300 and $500 \mathrm{~m}$ buffer zones, whereas land use did not affect submerged hydrophyte 
richness. In a recent work by Murphy et al. [46], it was stated that macrophytes generally have narrow rather than broad world distributions.

Table 2. Results of correlation analysis (Kendall tau) between diversity of macrophytes and assessed parameters. * significant correlations $(p<0.05)$, ns—non significant, RZ—riparian zone.

\begin{tabular}{ccc}
\hline & Taxa_S & Shannon_H \\
\hline pH & $-0.3325^{*}$ & $\mathrm{~ns}$ \\
conductivity & $\mathrm{ns}$ & $\mathrm{ns}$ \\
[O2] & $\mathrm{ns}$ & $\mathrm{ns}$ \\
water temperature & $\mathrm{ns}$ & $\mathrm{ns}$ \\
saturation (O2) & $\mathrm{ns}$ & $\mathrm{ns}$ \\
distance from the source & $-0.3306^{*}$ & $\mathrm{~ns}$ \\
land use & $0.3940^{*}$ & $0.3428^{*}$ \\
width of RZ & $\mathrm{ns}$ & $\mathrm{ns}$ \\
connectivity of RZ & $\mathrm{ns}$ & $\mathrm{ns}$ \\
vegetation structure of RZ & $\mathrm{ns}$ & $\mathrm{ns}$ \\
retention structures & $\mathrm{ns}$ & $\mathrm{ns}$ \\
shape of the channel & $\mathrm{ns}$ & $\mathrm{ns}$ \\
sediments in the channnel & $\mathrm{ns}$ & $\mathrm{ns}$ \\
bank structure & $\mathrm{ns}$ & $\mathrm{ns}$ \\
bottom of river & $\mathrm{ns}$ & $\mathrm{ns}$ \\
riffles, pools & $0.3411^{*}$ & $0.3774 *$ \\
detritus & $\mathrm{ns}$ & $\mathrm{ns}$ \\
\hline
\end{tabular}

Out of all macrophyte taxa listed, the genus Potamogeton included the highest species diversity. Five different species were recorded along the entire river, namely, Potamogeton crispus, P. lucens, P. natans, P. pectinatus, and P. perfoliatus. Representatives of the genus Potamogeton are considered to thrive in habitats with slow or moderate flow and fine substrate. In terms of nutrient content in water, mesotrophic or eutrophic water offer the best conditions for their growth [47]. Two of the mentioned species are reported as indicators of eutrophic waters, namely, P. crispus and P. pectinatus, together with Myriophyllum spicatum and Sparganium erectum $[33,47,48]$, which occurred in Ljubljanica River in both time periods. The species Nuphar luteum does not survive in waters with low nutrient levels and high current velocity [49]. In the Ljubljanica River, N. luteum was recorded in more than half of the sections of the river, where it occurred with a low abundance. M. spicatum was found in the last two sections only. In the eighteenth section, the species appeared with a high abundance, while in the last section, it was rare. The species is typically found in alkaline waters [50] and thrives in nutrient-rich environments [51]. Zelnik et al. [11] analyzed macrophyte, spatial, and environmental parameters in 906 stretches of the watercourses in Slovenia and identified 87 vascular plant taxa. Unlike in the present study, the most abundant species were M. spicatum, Phalaris arundinacea, and P. nodosus. It seems that environmental conditions in the Ljubljanica River do not offer appropriate conditions for the luxuriant growth for M. spicatum, which is otherwise the most abundant species in the majority of Slovenian rivers. The most probable reason for its absence is the presence of the invasive alien species Elodea canadensis, which has outcompeted M. spicatum, as the only two sections where M. spicatum is still present lack this invasive species. E. canadensis has become one of the most abundant species according to data from 2019.

A high abundancy of the species P. pectinatus was recorded in a broad band along the middle of the riverbed at the inflow of the Radna stream into the Ljubljanica River in the thirteenth section. Given the significant change in aquatic vegetation with the high abundance of P. pectinatus, we concluded that elevated nutrient concentrations are coming into the river at this location. P. pectinatus indicates nutrient-rich water [47], which is also consistent with the high levels of orthophosphates $(0.13 \mathrm{mg} / \mathrm{L})$ that were detected in section 18, where this species also appeared with high abundance.

Taxa that are characteristic of moderately nutrient-rich waters were also detected in the Ljubljanica River. Haslam [48] states that such conditions are characterized by the 
taxa Callitriche sp., Ranunculus sp., and Veronica anagallis-aquatica. Species of the genus Callitriche occurred with a high abundance in the upper part of the Ljubljanica River, while they appeared with low abundance in the sections of the river flowing through the city of Ljubljana. The species $V$. anagallis-aquatica, Ranunculus circinatus, and $R$. trichophyllus occurred in the upper part of the river but with low abundance. We rated them as rare species. From the sixteenth section onwards, none of the mentioned species appear in the river.

In the Ljubljanica River, Elodea canadensis reached very high RPA (Figure 3). It appeared with a high abundance in the upper sections, and then its abundance decreased slightly from the fifth to the thirteenth section and increased again in sections 14-16. The species was not present in the sections in the city of Ljubljana (sections 17 and 18) or in Podgrad (section 19) (Figure 2). E. canadensis is one of the most widespread invasive alien species in the world [52]. In some places, the species spread rapidly and displaced autochthonous species [53,54], while elsewhere, it did not show its invasive character $[55,56]$. E. canadensis has a high tolerance for different environmental factors, so it is found in almost all types of aquatic systems [57]. Depending on the nutrient contents, the species occurs in a wide range of environments, ranging from mesotrophic to eutrophic waters [58,59]. Kuhar and co-workers [56] state that the species in Slovenia most often occurs in rivers flowing through agricultural landscapes with a narrow and more-or-less disturbed riparian zone, with moderate presence of retention structures and sediment consisting of gravel, sand, and silt with coarse or fine organic particles. In general, the scarcity of knowledge about the majority of aquatic IAS prevents the suitable implementation of measures for the effective recovery of impacted ecosystems [60].
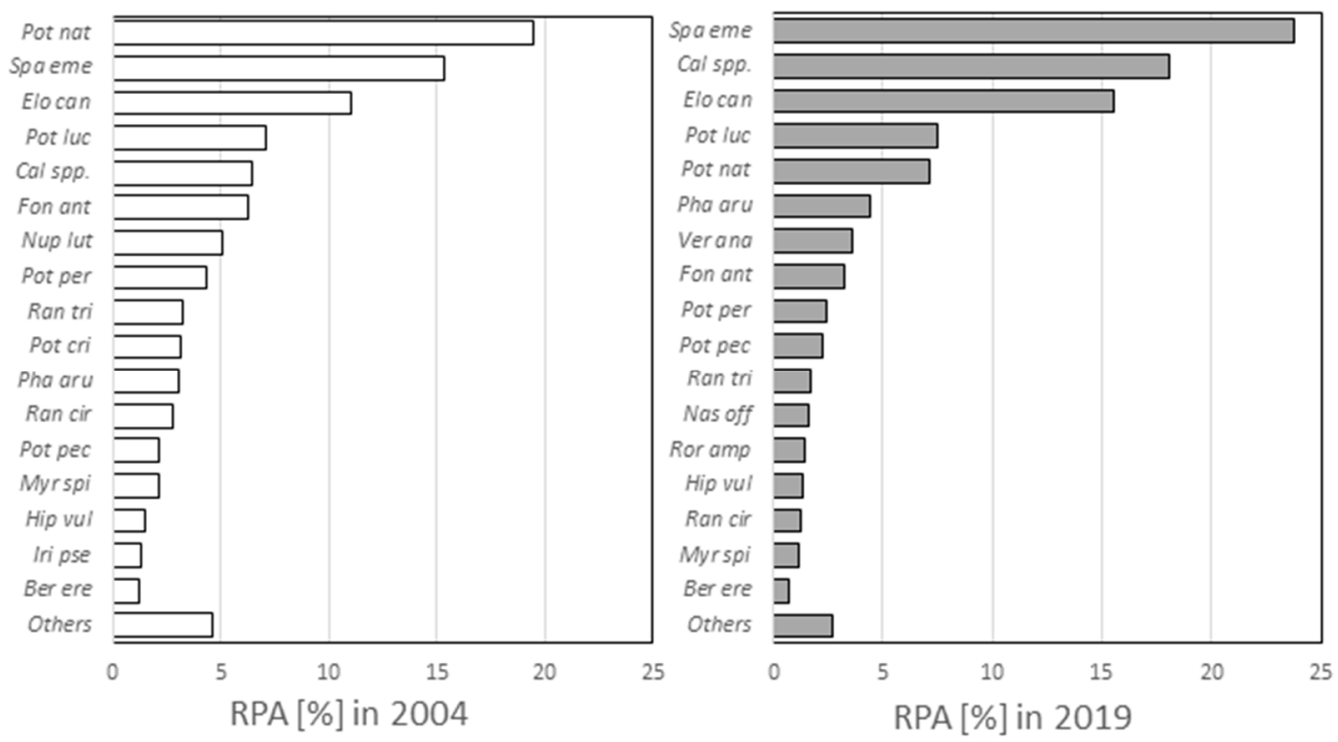

Figure 3. Comparison of the relative plant abundance (RPA) in different time periods. The value is expressed as a percentage and represents the biomass of each species in the watercourse.

Sparganium emersum was also an abundant and dominant species in the Ljubljanica River, appearing in all sections except for the final one before the confluence of the Ljubljanica and Sava Rivers (Figure 2). Of all the species, it occurred with the greatest abundance (Figure 3). Moderately eutrophic and eutrophic waters characterize the species. One of its advantages is that it tolerates shady areas [48]. The species appeared in the Ljubljanica River along the banks and at greater depths. In the field, we observed that the species occurred in the community with a variety of other macrophyte species, indicating a low level of competition, special habitat demands, and high phenotypic plasticity of the species [61].

Compared to the data presented by Šraj-Kržič et al. [40], minor changes in the diversity of macrophytes were observed (Table 1, Figure 3). The most obvious difference was in the 
presence of the species M. spicatum which, according to previous survey, occurred along the entire Ljubljanica, whereas in 2019, we recorded the species only in section 18 and observed a single plant in section 19. However, the species is considered a generalist and grows almost everywhere. The species grows rapidly, creating dense stands and shading other aquatic plants [62]. In lake Provala (Serbia), researchers evidenced that M. spicatum formed predominantly monospecific stands, demonstrating its allelopathic activity [63]. A possible reason for the absence of the species in the upper and middle parts of the river is the high competitiveness of other species or the invasiveness of E. canadensis, which expressed its invasive character in the Ljubljanica River with its high abundance. Alien aquatic plants can drastically transform the structure of freshwater habitats and their water quality [64]. There is also an important change in the occurrence of the species S. emersum in this time period, which increased in abundance by $50 \%$ (Figure 3), according to data from 2004 [40]. In this study, the mentioned species appeared with great abundance in sections in the middle part of the Ljubljanica (Figure 2).

Detrended correspondence analysis showed more intense clustering of the locations along the river flow, based on macrophyte species data from 2019 than in previous research [40], indicating the homogenization trend of vegetation (Figure 4), since the majority of locations along the flow were less scattered in 2019 than in 2004. Homogenization of aquatic vegetation across a longer time frame was reported by Lindholm et al. [22]. The exception was the two final locations, where the river leaves the city of Ljubljana, which differed from other locations even more so than in the previous research [40].

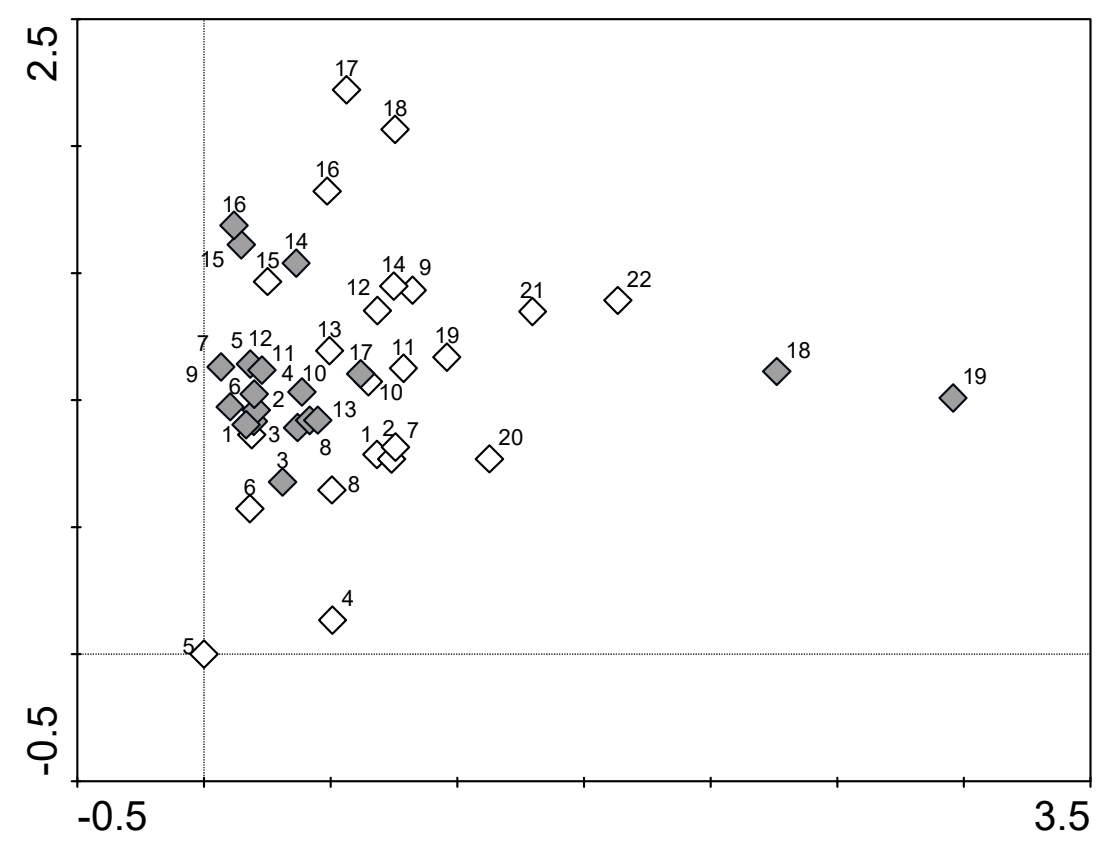

Figure 4. DCA plot showing the clustering of locations along the river flow based on different macrophyte species' presence and abundance. White diamonds-2004, grey diamonds—2019.

Canonical correspondence analysis revealed that distance from the source was one of the most important parameters that significantly influenced the distribution of macrophytes, apart from RCE parameters (Table 3), and it was highly significantly correlated with species diversity in Slovenian rivers [11]. 
Table 3. Results of canonical correspondence analysis (CCA) parameters between diversity of macrophytes and assessed parameters. Only parameters that significantly influenced the distribution of macrophytes are listed (TVE—-total variance explained).

\begin{tabular}{cccc}
\hline Variable & LambdaA & $p$ & \% of TVE \\
\hline retention structures & 0.55 & 0.002 & 34.9 \\
conectivity of RZ & 0.13 & 0.006 & 8.2 \\
distance from source & 0.13 & 0.004 & 8.2 \\
channel shape & 0.11 & 0.022 & 7.0 \\
sediments in the channnel & 0.1 & 0.036 & 6.3 \\
\hline
\end{tabular}

The analysis of environmental factors showed that the greatest influences on the abundance and distribution of macrophytes besides the distance from the source were retention structures in the riverbed, the connectivity of the riparian zone vegetation, the shape of the riverbed, and sediments in the riverbed (Table 3). The occurrence of macrophytes was significantly influenced by the retention structures in the river. Larger patches of macrophytes appeared in some areas next to fallen trees in the water. The completeness of the riparian zone vegetation, in connection with shading, mainly influenced the appearance of E. canadensis and S. emersum. In the more open, sunny parts of the river, a high abundance of E. canadensis was observed, while S. emersum predominated in shady areas.

Similarly, as in the present study, macrophytes' growth was affected by the riparian vegetation in the study conducted by Ali et al. [65]. The authors found a significant difference in both the type and density of submerged macrophytes growing under shaded areas as compared to unshaded areas regarding riparian woody vegetation. In the upper and middle part of the river, the form of the riverbed, which is defined as the ratio between width and depth, also had a great influence on the distribution of macrophytes.

\section{Conclusions}

In 2019, a total of 34 different macrophyte taxa were observed in the river (compared to 37 in 2004), of which the taxa Callitriche sp., Elodea canadensis, and Sparganium emersum appeared with the highest abundancy. Their appearance reflects the loading of the water with nutrients. The diversity of macrophytes is very high and comparable to that observed in historical data. The most outstanding differences were the decrease in the presence and abundance of $P$. natans and the presence of the species Myriophyllum spicatum, which was very abundant in 2004 but was only recorded in the last two sections in 2019, possibly as a consequence of the increased presence and abundance of the invasive alien species Elodea canadensis.

Author Contributions: Conceptualization, A.G. and M.G.; methodology, A.G. and M.G.; validation, A.G., M.G., and V.J.; formal analysis, A.G., M.G., and I.Z.; investigation, A.G., M.G., and V.J.; writing-original draft preparation, M.G. and V.J.; writing—review and editing, M.G., A.G., and I.Z.; visualization, A.G., M.G., and I.Z.; supervision, M.G.; project administration, A.G.; funding acquisition, A.G. All authors have read and agreed to the published version of the manuscript.

Funding: This research was funded by Research Agency of the Republic of Slovenia, Research programs Biology of plants (P1-0212).

Institutional Review Board Statement: Not applicable.

Informed Consent Statement: Not applicable.

Data Availability Statement: Data are stored within the documentation of P1-0212 Research program.

Acknowledgments: Authors thank to Matej Holcar for creation of the Figure 1.

Conflicts of Interest: The authors declare no conflict of interest. The funders had no role in the design of the study; in the collection, analyses, or interpretation of data; in the writing of the manuscript; or in the decision to publish the results. 


\section{References}

1. Borgwardt, F.; Robinson, L.; Trauner, D.; Teixeira, H.; Nogueira, A.J.A.; Lillebø, A.I.; Piet, G.; Kuemmerlen, M.; O’Higgins, T.; McDonaldg, H.; et al. Exploring variability in environmental impact risk fromhuman activities across aquatic ecosystems. Sci. Total Environ. 2019, 652, 1396-1408. [CrossRef]

2. Grime, J.P. Biodiversity and ecosystem function: The debate deepens. Science 1997, 277, 1260-1261. [CrossRef]

3. Grime, J. Benefits of plant diversity to ecosystems: Immediate, filter and founder effects. J. Ecol. 1998, 86, 902-910. [CrossRef]

4. Díaz, S.; Cabido, M. Vive la difference: Plant functional diversity matters to ecosystem processes. Trends Ecol. Evol. 2001, 16, 646-655. [CrossRef]

5. Gallardo, B.; Clavero, M.; Sánchez, M.I.; Vilá, M. Global ecological impacts of invasive species in aquatic ecosystems. Glob. Chang. Biol. 2016, 22, 151-163. [CrossRef]

6. Vilá, M.; Hulme, P.E. Non-native Species, Ecosystem Services, and Human Well-Being. In Impact of Biological Invasions on Ecosystem Services; Springer: Berlin/Heidelberg, Germany, 2017; pp. 1-14.

7. Franklin, P.; Dunbar, M.; Whitehead, P. Flow controls on lowland river macrophytes: A review. Sci. Total Environ. 2008, 400, 369-378. [CrossRef] [PubMed]

8. Allan, J.D. Landscapes and riverscapes: The influence of land use on stream ecosystems. Annu. Rev. Ecol. Evol. Syst. 2004, 35, 257-284. [CrossRef]

9. Vörösmarty, C.J.; Mclntyre, P.B.; Gessner, M.O.; Dudgeon, D.; Prusevich, A.; Green, P.; Glidden, S.; Bunn, S.E.; Sullivan, C.A.; Liermann, C.R. Global threats to humanwater security and river biodiversity. Nature 2010, 467, 555. [CrossRef]

10. Szoszkiewicz, K.; Ferreira, T.; Korte, T.; Baattrup-Pedersen, A.; Davy-Bowke, J.; O’Hare, M. European River Plant Communities: The Importance of Organic Pollution and the Usefulness of Existing Macrophyte Metrics. Hydrobiologia 2006, 566, 211-234. [CrossRef]

11. Zelnik, I.; Kuhar, U.; Holcar, M.; Germ, M.; Gaberščik, A. Distribution of vascular plant communities in Slovenian watercourses. Water 2021, 13, 1071. [CrossRef]

12. Fennessy, M.S.; Geho, R.; Elifritz, B.; Lopez, R.D. Testing the Floristic Quality Assessment Index as an Indicator of Riparian Wetland Disturbance; Ohio Environmental Protection Agency, Division of Surface Water: Columbus, OH, USA, 1998.

13. Mack, J.J.; Micacchion, M.; Augusta, L.D.; Sablack, G.R. Vegetation Indices of Biotic Integrity (Vibi) for Wetlands and Calibration of the Ohio Rapid Assessment Method for Wetlands; Grant CD95276; Final Report to US Environmental Protection Agency; Ohio Environmental Protection Agency: Columbus, OH, USA, 2000; p. 98.

14. Aznar, J.; Dervieux, A.; Grillas, P. Association between aquatic vegetation and landscape indicators of human pressure. Wetlands 2002, 23, 149-160. [CrossRef]

15. Bornette, G.; Amoros, C.; Chessel, D. Effect of allogenic processes on successional rates in former river channels. J. Veg. Sci. 1994, 5, 237-246. [CrossRef]

16. O'Hare, M.T.; Baattrup-Pedersen, A.; Nijboer, R.; Szoszkiewicz, K.; Ferreira, T. Macrophyte communities of European streams with altered physical habitat. Hydrobiologia 2006, 566, 197-210. [CrossRef]

17. Yang, N.; Zhang, Y.; Duan, K. Effect of Hydrologic Alteration on the Community Succession of Macrophytes at Xiangyang Site, Hanjiang River, China. Scientifica 2017, 2017, 4083696. [CrossRef] [PubMed]

18. Mackay, S.J.; Arthington, A.H.; Kennard, M.J.; Pusey, B.J. Spatial variation in the distribution and abundance of submerged macrophytes in an Australian subtropical river. Aquat. Bot. 2003, 77, 169-186. [CrossRef]

19. Kuhar, U.; Germ, M.; Gaberščik, A.; Urbanič, G. Development of a River Macrophyte Index (RMI) for assessing river ecological status. Limnologica 2011, 41, 235-243. [CrossRef]

20. Hatton-Ellis, T.W.; Grieve, N.; Newman, J. Ecology of watercourses characterised by Ranunculion fluitantis and CallitrichoBatrachion vegetation. Conserving Natura 2000 rivers ecology series. Engl. Nat. 2003, 11, 67.

21. Halabowski, D.; Lewin, I. Impact of anthropogenic transformations on the vegetation of selected abiotic types of rivers in two ecoregions (Southern Poland). Knowl. Manag. Aquat. Ecosyst. 2020, 421, 35. [CrossRef]

22. Lindholm, M.; Alahuhta, J.; Heino, J.; Hjort, J.; Toivonen, H. Changes in the functional features of macrophyte communities and driving factors across a 70-year period. Hydrobiologia 2020, 847, 3811-3827. [CrossRef]

23. Sand-Jensen, K.; Jeppesen, E.; Nielsen, K.; Van Der Bijl, L.; Hjermind, L.; Nielsen, L.W.; Iversen, T.M. Growth of macrophytes and ecosystem consequences in a lowland Danish stream. Freshw. Biol. 1989, 22, 15-32. [CrossRef]

24. Milner, A.M. System recovery. In The Rivers Handbook: Hydrological and Ecological Principles; Calow, P., Petts, G.E., Eds.; Blackwell Science Ltd.: Oxford, UK, 1994; Volume 2, pp. 76-97.

25. Underwood, A.J. Spatial and temporal problems with monitoring. In The Rivers Handbook: Hydrological and Ecological Principles; Calow, P., Petts, G.E., Eds.; Blackwell Science Ltd.: Oxford, UK, 1994; Volume 2, pp. 101-123.

26. Viciani, D.; Vidali, M.; Gigante, D.; Bolpagni, R.; Villani, M.; Acosta, A.T.R.; Adorni, M.; Aleffi, M.; Allegrezza, M.; Angiolini, C.; et al. A first checklist of the alien-dominated vegetation in Italy. Plant Sociol. 2020, 57, 29-54. [CrossRef]

27. Zelnik, I.; Mavrič-Klenovšek, V.; Gaberščik, A. Complex undisturbed riparian zones are resistant to colonisation by invasive alien plant species. Water 2020, 12, 345. [CrossRef]

28. Directive 2000/60/EC of the European Parlament and of the Council of 23 October 2000. Available online: https:/ / eur-lex. europa.eu/eli/dir/2000/60/oj (accessed on 8 October 2020). 
29. Feio, M.J.; Aguiar, F.C.; Almeida, S.F.P.; Ferreira, J.; Ferreira, M.T.; Elias, C.; Serra, S.R.Q.; Buffagni, A.; Cambra, J.; Chauvin, C.; et al. Least Disturbed Condition for European Mediterranean rivers. Sci. Total Environ. 2014, 476-477, 745-756. [CrossRef]

30. Urbanc-Berčič, O.; Germ, M.; Povž, M.; Šumer, S. Evaluation of Ecological Status of the River Ljubljanica: Macrophytes and Fishes; Nacionalni Inštitut za Biologijo: Ljubljana, Slovenia, 2007; 47p.

31. Pavšič, J. The Ljubljansko Barje Marshes; Društvo Slovenska Matica: Ljubljana, Slovenia, 2008.

32. Kohler, A. Methoden der kartierung von flora und vegetation von sußwasserbiotopen. Landsch. Stadt 1978, 10, 78-85.

33. Schneider, S.; Melzer, A. The Trophic Index of Macrophytes (TIM)-A New Tool for Indicating the Trophic State of Running Waters. Int. Rev. Hydrobiol. 2003, 88, 49-67. [CrossRef]

34. Petersen, R.C. The RCE: A riparian, channel, and environmental inventory for small streams in the agricultural landscape. Freshw. Biol. 1992, 27, 295-306. [CrossRef]

35. Pall, K.; Janauer, G.A. Die Makrophytenvegetationvon Flußstauen am Beispiel der Donau zwischen Fluß-km2552,0 und 2511,8 in der Bundesrepublik Deutschland. Arch. Hydrobiol. Suppl. Large Rivers 1995, 9, 91-109.

36. Braun-Blanquet, J. Pflanzensoziologie, Grundzüge der Vegetationskunde, 3rd ed.; Springer: Berlin, Germany, $1964 ;$ p. 631.

37. Hammer, Ø.; Harper, D.A.T.; Ryan, P.D. PAST: Paleontological statistics software package for education and data analysis. Palaeontol. Electron. 2001, 4, 1-9.

38. ter Braak, C.J.F.; Smilauer, P. CANOCO Reference Manual and CanoDraw for Windows User's Guide: Software for Canonical Community Ordination (Version 4.5); Microcomputer Power: Ithaca, NY, USA, 2002.

39. ter Braak, C.J.F.; Verdonschot, P.F.M. Canonical correspondence analysis and related multivariate methods in aquatic ecology. Aquat. Sci. 1995, 57, 255-289. [CrossRef]

40. Šraj-Kržič, N.; Germ, M.; Urbanc-Berčič, O.; Kuhar, U.; Janauer, G.A.; Gaberščik, A. The quality of the aquatic environment and macrophytes of karstic watercourses. Plant Ecol. 2007, 192, 107-118. [CrossRef]

41. Lacoul, P.; Freedman, B. Environmental influences on aquatic plants in freshwater ecosystems. Environ. Rev. 2006, 14, 89-136. [CrossRef]

42. Ljevnaić-Mašić, B.; Džigurski, D.; Nikolić, L.; Brdar-Jokanović, M.; Čabilovski, R.; Ćirić, V.; Petrović, A. Assessment of the habitat conditions of a rare and endangered inland saline wetland community with Bolboschoenus maritimus (L.) Palla dominance in Southeastern Europe: The effects of physical-chemical water and soil properties. Wetl. Ecol. Manag. 2020, 28, 421-438. [CrossRef]

43. Svitok, M.; Hrivnák, R.; Kochjarová, J.; Ot'ahel’ová, H.; Pal'ove-Balang, P. Environmental thresholds and predictors of macrophytespecies richness in aquatic habitats in central Europe. Folia Geobot. 2016, 51, 227-238. [CrossRef]

44. Rosso, J.J.; Fernández Cirelli, A. Effects of land use on environmental conditions and macrophytes in prairie lotic ecosystems Limnologica 2013, 43, 18-26. [CrossRef]

45. Alahuhta, J.; Kanninen, A.; Hellsten, S.; Vuori, K.-M.; Kuoppala, M.; Hämäläinen, H. Variable response of functional macrophyte groups to lake characteristics, land use, and space: Implications for bioassessment. Hydrobiologia 2014, 737, 201-214. [CrossRef]

46. Murphy, K.; Efremov, A.; Davidson, T.A.; Molina-Navarro, K.E.; Fidanza, T.C.; Crivelari Betiol, P. Chambers, Julissa Tapia Grimaldo, Sara Varandas Martins, Irina Springuel, Michael Kennedy, Roger Paulo Mormul, Eric Dibble, Deborah Hofstra, Balázs András Lukács, Daniel Gebler, Lars Baastrup-Spohr, Jonathan Urrutia-Estrada. World distribution, diversity and endemism of aquatic macrophytes. Aquat. Bot. 2019, 158, 103127.

47. Preston, C. Pondweeds of Great Britain and Ireland; Botanical Society of the British Isles: London, UK, $1995 ;$ p. 352.

48. Haslam, S.M. River plants of western europe. In The Macrophytic Vegetation of Watercourses of the European Economic Community; Cambridge University Press: Cambridge, UK, 1987; p. 511.

49. Schneider, S. Macrophyte trophic indicator values from a European perspective. Limnol. Ecol. Manag. Inland Waters 2007, 37, 281-289. [CrossRef]

50. Patten, B.C., Jr. The status of some American species of Myriophyllum as revealed by the discovery of intergrade material between M. exalbescens Fern. and M. spicatum L. in New Jersey. Rhodora 1954, 56, 213-225.

51. Aiken, S.G.; Newroth, P.R.; Wile, I. The biology of Canadian weeds: 34. Myriophyllum spicatum L. Can. J. Plant Sci. 1979, 59, 201-215. [CrossRef]

52. Hussner, A. Alien aquatic plants in European countries. Weed Res. 2012, 52, 297-306. [CrossRef]

53. Hussner, A.; Hoelken, H.P.; Jahns, P. Low Light acclimated submerged freshwater plants show a pronounced sensitivity to increasing irradiances. Aquat. Bot. 2010, 93, 17-24. [CrossRef]

54. Mjelde, M.; Lombardo, P.; Berge, D.; Johansen, W.S. Mass invasion of non-native Elodea canadensis Michx. In a large, clear-water, species-rich Norwegian lake-Impact on macrophyte biodiversity. Ann. Limnol. Int. J. Limnol. 2012, 48, 225-240. [CrossRef]

55. Josefsson, M.; Andersson, B. The environmental consequences of alien species in the Swedish lakes Mälaren, Hjälmaren, Vänern and Vättern. Ambio 2001, 30, 514-521. [CrossRef]

56. Kuhar, U.; Germ, M.; Gaberščik, A. Habitat characteristic of an alien species Elodea canadensis in Slovenian watercourses. Hydrobiologia 2010, 656, 205-212. [CrossRef]

57. Kłosowski, G.; Kłosowski, S. Flora Polski. Rośliny Wodne i Bagienne; Multico: Warszawa, Poland, 2015; p. 336.

58. Szoszkiewicz, K.; Zbierska, J.; Jusik, S.; Zgoła, T. Macrophyte Method for River Assessment. A Methodological Manual on the Assessment and Classification of the Ecological Status of Flowing Waters Based on Aquatic Plants; Bogucki Wydawnictwo Naukowe: Poznan, Poland, 2010; pp. 1-78. 
59. Haury, J.; Peter, M.C.; Termolieres, M.; Barbe, J.; Thiebaut, G.; Bernez, I.; Daniel, H.; Chatenet, P.; Haane-Archipof, G.; Muller, S.; et al. A new method to access water trophy and organic pollution-The Macrophite Biological Index for Rivers (IBMR): Its application to different types of river and pollution. Hydrobiologia 2006, 1, 153-158.

60. Lazzaro, L.; Bolpagni, R.; Buffa, G.; Gentili, R.; Lonati, M.; Stinca, A.; Acosta, A.T.R.; Adorni, M.; Aleffi, M.; Allegrezza, M.; et al. Impact of invasive alien plants on native plant communities and Natura 2000 habitats: State of the art, gap analysis and perspectives in Italy. J. Environ. Manag. 2020, 274, 111140. [CrossRef]

61. Cook, C.D.; Nicholls, M.S. A monographic study of the genus Sparganium (Sparganiaceae). Part 1. Subgenus Xanthosparganium Holmberg. Bot. Helv. 1986, 96, 213-267.

62. Ceska, O.; Ceska, A. Myriophyllum haloragaceae L. species in British Columbia: Problems with identification. In Proceedings of the First International Symposium on Watermilfoil, Vancouver, BC, Canada, 23-24 July 1985.

63. Nikolić, L.; Pajević, S.; Ljevnaić, B. Primary production dynamics of dominant hydrophytes in Lake Provala (Serbia). Cent. Eur. J. Biol. 2009, 4, 250-257. [CrossRef]

64. Brundu, G.; Stinca, A.; Angius, L.; Bonanomi, G.; Celesti-Grapow, L.; D'Auria, G.; Griffo, R.; Migliozzi, A.; Motti, R.; Spigno, P. Pistia stratiotes L. and Eichhornia crassipes (Mart.) Solms.: Emerging invasive alien hydrophytes in Campania and Sardinia (Italy). Bull. OEPP/EPPO Bull. 2012, 42, 568-579. [CrossRef]

65. Ali, M.M.; Hassan, S.A.; Shaheen, A.-S.M. Impact of riparian trees shade on aquatic plant abundance in conservation islands. Acta Bot. Croat. 2011, 70, 245-258. [CrossRef] 